\title{
SPATIAL HETEROGENEITY OF TOPSOIL MOISTURE AND IMPACT OF VEGETATION FACTORS ON ITS DISTRIBUTION UNDER PURE AND MIXED BLACK LOCUST (ROBINIA PSEUDOACACIA L.) AND CHINESE RED PINE (PINUS TABULAEFORMIS CARR.) FORESTS ON THE LOESS PLATEAU IN CHINA
}

\author{
LIANG, W. J. ${ }^{1}-$ WEI, X. ${ }^{1,2^{*}}$ \\ ${ }^{1}$ College of Forestry, Shanxi Agricultural University, Taigu 030801, P.R. China \\ ${ }^{2}$ Ji County Station, Chinese National Ecosystem Research Network (CNERN), Beijing 100083, \\ P.R. China \\ Corresponding author \\ e-mail:weixi@sxau.edu.cn
}

(Received 21 $1^{\text {st }}$ Oct 2020; accepted $21^{\text {st }}$ Dec 2020)

\begin{abstract}
To determine the contribution of overstory and understory flora on soil water content in typical forest plantations on the Loess Plateau, standard sampling plots were established in five pure Robinia pseudoacacia L. and five pure Pinus tabulaeformis Carr. plantations, together with five more plots in mixed forests of both species. The relationships between the overstory structure, herbaceous diversity, soil water, and nutrients were analyzed using statistical methods including feature, geostatistical, and Pearson's correlation analyses. The results indicated that the topsoil moisture content of the pure forests (12.80\% and $11.97 \%$, respectively) was greater than that of the mixed forest $(6.75 \%)$, but significantly lower than that of a grassland (26.97\%). The canopy leaf area index (LAI), herbaceous Shannon-Wiener index, Simpson's index, and total nitrogen (TN) were important factors controlling the distribution of soil moisture (the absolute values of their correlation coefficients were more than 0.5). The spatial heterogeneity of topsoil moisture was greatest in the pure Robinia pseudoacacia $\mathrm{L}$. forests. It was found that appropriately increasing and decreasing the significant controlling factors, including LAI, herb diversity, and soil TN, could improve the soil moisture content and mitigate its spatial heterogeneity to improve the growth of vegetation on the Loess Plateau.
\end{abstract}

Keywords: overstory and understory flora, stand structure, herbaceous diversity, topsoil water distribution, soil properties

\section{Introduction}

Soil water in the ecosystem is the basis of plant survival, and is also an important factor restricting the growth of trees (Pueyo et al., 2014; Ma et al., 2020). On the Loess Plateau, afforestation and vegetation restoration have improved the provision of ecosystem services and the functioning of the region in recent decades (Shen et al., 2018). However, the large-scale planting of artificial forests has resulted in the consumption of excessive water and increasingly dry soil layers.

To examine the causes of these problems, most studies have focused on the structure and function of the Loess Plateau ecosystem and other ecologically sensitive areas. For example, chronic water stress can reduce forest growth (Brzostek et al., 2014), and soil water content is also affected by terrain, climate, and plant survival (Liu et al., 2018). Previous studies have reached similar conclusions regarding forest structure, soil moisture (Li et al., 2016; Martínez-Murillo et al., 2017), and soil physical and chemical properties (Shi et al., 2017). Environmental heterogeneity (including the temporal and 
spatial heterogeneity of terrain, climate, soil, or water) is a well-recognized influence on plant communities because species differ both in their responses to and their effects on soil characteristics (Smith and Knapp, 2006; Li et al., 2018). The environmental indicators of different tree species are significantly varied, such as the overstory leaf area index (LAI) and transpiration rate, and the Shannon-Wiener $\left(H^{\prime}\right)$, Simpson's $(D)$, and Pielou $(J)$ indexes of the herbs in the understory. The LAI incorporates many eco-physiological processes and can be used to scale-up leaf and water processes to ecosystem and even regional levels (Liu et al., 2018). In contrast, the diversity indexes reflect the growth of understory herbs (Sánchez-González and López-Mata, 2005).

Plant species differ in their responses to the spatial heterogeneity of resources (Grime, 1994; Endara and Jaramillo, 2011), and at the same time they create spatial heterogeneity in the process of adapting to different environments (Eldridge et al., 2019; Yu et al., 2019; Ahmad et al., 2020). Previous studies found no significant effect of plants on the spatial heterogeneity of soil moisture content (Farley and Fitter, 1999; Ronda et al., 2002). We investigated the effects of both trees and herbs on the spatial heterogeneity of soil moisture content within a semiarid region, the Western Shanxi Province, in China. Generally, the between-year variability in rainfall on a slope scale is significantly greater for grasslands than forests (Smith and Knapp, 2006), indicating that grasses face a selection pressure in overcoming the spatial heterogeneity in soil moisture content (Western et al., 1998; Sreelash et al., 2018). Grasses have the ability to amplify the spatial heterogeneity of soil moisture, and through their water uptake might reduce soil moisture to a much greater extent than woody plants, which could eventually remove trees from grasslands (Qi et al., 2004; Wubs and Bezemer, 2018). The large potential water absorption of grasses may change the spatial variability of soil moisture content in grasslands and forest-grass mixed areas. To evaluate this, two representative species, black locust (Robinia pseudoacacia L.) and Chinese red pine (Pinus tabulaeformis Carr.), growing together with understory herbs were selected to conduct a field investigation in the region.

There is much uncertainty about the significance and direction of how differences between tree species and their understory flora are impacted by differences in terms of the spatial heterogeneity of soil moisture content, and the causes of the differences are also not clear. We considered the environmental heterogeneity, including climate characteristics, forest cover, water, soil type, topography, geomorphology, and development of the area, comprehensively in this study. It was hypothesized that there were significant differences in the soil moisture content between areas covered by trees and herbs, and the canopy interception and plant uptake made different contributions to soil moisture under the different plant covers. The mechanism and process of the competition for water use between forests and grassland were quantitatively analyzed, and the impact factors of the spatial heterogeneity in soil moisture were identified. The results provide a reference for the comprehensive utilization of soil water and the optimization of the overstory and understory vegetation on the Loess Plateau.

\section{Materials and methods}

\section{Site description}

The experimental field site was located in the nested Caijiachuan watershed, which is a typical gully area of the Loess Plateau in Ji County, Shanxi Province, China. The longitude and latitude were $35^{\circ} 53^{\prime}-36^{\circ} 21^{\prime} \mathrm{N}$ and $110^{\circ} 27^{\prime}-111^{\circ} 7^{\prime} \mathrm{E}$, respectively, and 
the elevation ranged from 904 to $1592 \mathrm{~m}$ a.s.l. The annual mean temperature of the area is $10.2^{\circ} \mathrm{C}$, the annual mean precipitation is $571 \mathrm{~mm}$, and the annual mean potential evapotranspiration (PET) is $1724 \mathrm{~mm}$. The region therefore has the typical features of a continental climate, with the PET being more than three times the annual rainfall. The soil is a Haplic Luvisol, according to the soil classification of the Food and Agriculture Organization of the United Nations (FAO). The vegetation is characterized by artificial shelterbelts of black locust (Robinia pseudoacacia L.) and Chinese red pine (Pinus tabulaeformis Carr.), with a forest cover of up to $72 \%$ over an area of $38 \mathrm{~km}^{2}$. Additional details of the shrubs present in the area have been published elsewhere (Wei et al., 2018), with the dominant herbaceous species being Artemisia sacrorum Ledeb., Patrinia scabiosifolia, Carex rigescens, Rubia cordifolia L., Metaplexis japonica (Thunb.) Makino.

\section{Field observations and soil sampling}

We examined the spatial variability of the shallow soil moisture content in 15 standard plots $(20 \times 20 \mathrm{~m})$, including five in pure Robinia pseudoacacia $\mathrm{L}$. and five in pure Pinus tabulaeformis Carr. Plots, together with five in mixed forests composed of both species. The plots were scattered along different ravines in the same watershed, to ensure that precipitation and soils were as similar as possible (Fig. 1). Additionally, we selected five grassland monocultures as control groups to ensure the reliability of the experimental design (Fig. 2). The details of the standard sampling plots in the watershed was shown in Table 1 by surveyed.

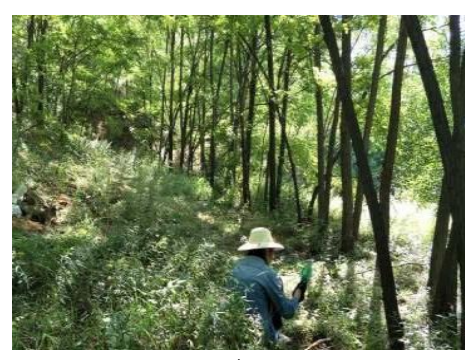

A

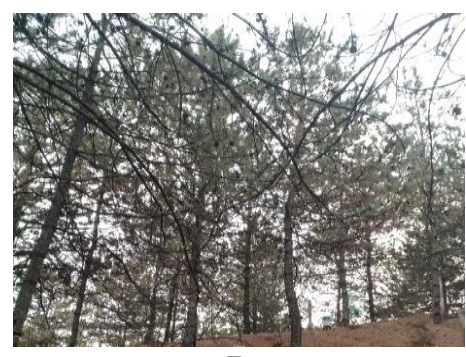

B

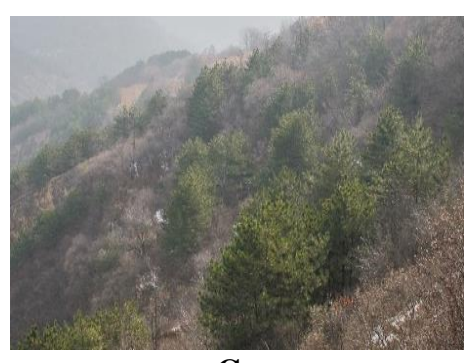

C

Figure 1. Images of selected sampling plots. (A) Robinia pseudoacacia L.; (B) Pinus tabulaeformis Carr.; (C) Mixed forest

Field surveys and measurements were conducted for all woody plants with diameters at breast height $(\mathrm{DBHs}) \geq 5 \mathrm{~cm}$ per plot $(\mathrm{DBH}$ measured to the nearest $0.1 \mathrm{~cm})$ during the summer growing season of 2017. The LAI of these plots was collected using a plant canopy analyzer (LAI-2000, LI-COR Company, Lincoln, NE, USA) in the morning, with no direct sunlight. Three LAI measurements were taken randomly in each plot, and their mean values were the representations of the stands. Herb layers under the forests were investigated by randomly arranging three quadrats of $1 \times 1 \mathrm{~m}$ for calculating the indicators of richness (number of species), biodiversity, including the Shannon-Wiener index $\left(H^{\prime}=-\sum_{i=1}^{S} p_{i} \ln p_{i}\right)$ and Simpson's index $\left(D=1-\sum_{i=1}^{S} p_{i}^{2}\right)$, and evenness (Pielou index: $J=H^{\prime} / \ln S$ ) (Shannon and Wiener, 1949; Simpson, 1949; Pielou, 1966; Daniel et al., 2019). The transpiration rate was measured by the weighing method (Takagi et al., 2006). The shallow soil volumetric moisture content at 0-20 cm depth was measured every $2 \mathrm{~m}$ by a soil probe (TDR 300, Spectrum Technologies, Inc., 
Plainfield, IL, USA), in a rectangular shaped alternating ridge and slope collection scheme (Fig. 3). All the sampling positions were measured unless there were large rocks or stout roots belowground, and the number of measurements per plot was $>80$. To avoid the influence of rainfall, soil moisture was measured at least three days after rain. Three replicated samples were established per plot, and soil samples $(0-20 \mathrm{~cm})$ were collected using a soil auger to represent the topsoil of the whole plot. After the air-dried soil samples were sieved $(0.15 \mathrm{~mm}$ mesh sieve), the soil organic matter (SOM), total nitrogen $(\mathrm{TN})$, total phosphorus $(\mathrm{TP})$, ammonia-nitrogen $\left(\mathrm{NH}_{3}-\mathrm{N}\right)$, nitrate-nitrogen $\left(\mathrm{NO}_{3}-\mathrm{N}\right)$, and available phosphorus (AP) contents were measured in the laboratory (Wei et al., 2018), using a SmartChem-200 Discrete Wet Chemistry Analyzer (AMS/Alliance Instruments, Paris, France).

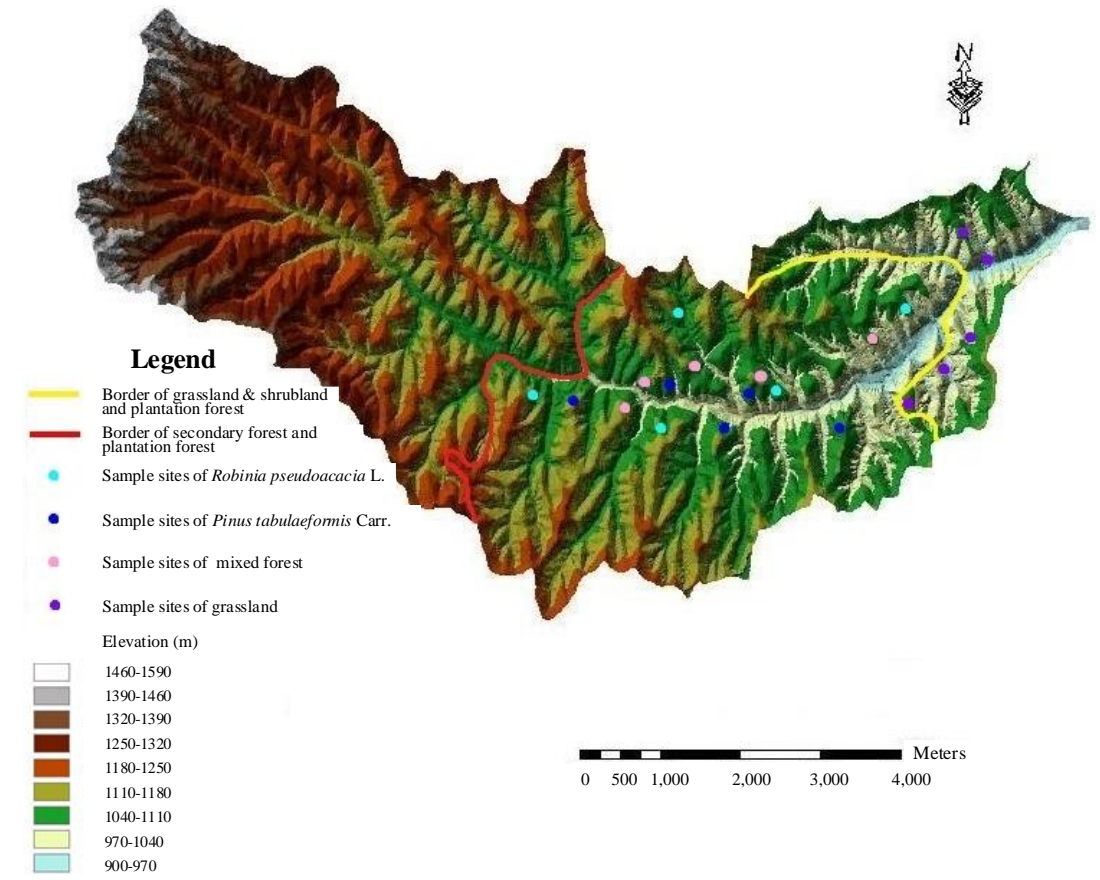

Figure 2. The distribution of the thirteen sampling plots in the watershed

\section{Data collection}

Forest characteristics were calculated, including DBH, tree height, crown area, stand density, canopy density, overstory LAI, the number of species (N), Shannon-Wiener index $\left(H^{\prime}\right)$, Simpson's index $(D)$, and Pielou index $(J)$ for both overstory and understory flora. Soil moisture and nutrients were measured and calculated (Daniel et al., 2019). Based on these indicators, a geostatistical analysis of soil moisture was conducted, using the kriging interpolation approach (Krige, 1966). The relationships between the spatial heterogeneity of the soil moisture, the overstory woody plants, and the understory herbaceous plants should be explored to determine the influence of the recommended soil moisture distribution on the vegetation. Correlations between trees, herbs, and soils were analyzed using SPSS 19.0 (IBM/International Business Machines Corporation, Armonk, NY, USA), and a geostatistical analysis of soil moisture was performed using the software Suffer 11.0 (Golden Software, Inc., Golden CO, USA). 
Table 1. Details of the standard sampling plots in the watershed

\begin{tabular}{|c|c|c|c|c|c|c|c|c|}
\hline Sample number & Abbreviation & Elevation(m) & $\begin{array}{c}\text { Slope } \\
\left({ }^{\circ}\right)\end{array}$ & Aspect & $\begin{array}{c}\text { Stand density } \\
\left(\text { trees}^{\prime} \text { hectare }^{-1}\right)\end{array}$ & $\begin{array}{c}\text { Average } \\
\text { DBH }^{\mathbf{a}} \\
(\mathrm{cm})\end{array}$ & $\begin{array}{c}\text { Average tree } \\
\text { height } \\
(\mathrm{m})\end{array}$ & $\begin{array}{c}\text { Average crown } \\
\text { area } \\
\left(\mathbf{m}^{\mathbf{2}}\right)\end{array}$ \\
\hline No.1 of black locust & BL1 & 1160 & 39 & semi-shady & 900 & 14.64 & 9.7 & 8.38 \\
\hline No. 2 of black locust & BL2 & 1140 & 26 & shady & 1200 & 9.93 & 8.7 & 5.75 \\
\hline No.3 of black locust & BL3 & 1190 & 22 & semi-shady & 1675 & 8.01 & 4.5 & 5.81 \\
\hline No. 4 of black locust & BL4 & 1120 & 22 & semi-sunny & 2075 & 12.29 & 9.9 & 11.82 \\
\hline No.5 of black locust & BL5 & 1120 & 15 & semi-shady & 2525 & 10.11 & 8.8 & 6.10 \\
\hline No.1 of Chinese red pine & $\mathrm{CP} 1$ & 1150 & 30 & semi-sunny & 700 & 13.47 & 6.9 & 9.27 \\
\hline No. 2 of Chinese red pine & $\mathrm{CP} 2$ & 1130 & 35 & shady & 1200 & 12.82 & 6.4 & 12.27 \\
\hline No. 3 of Chinese red pine & $\mathrm{CP} 3$ & 1150 & 26 & semi-shady & 1250 & 14.11 & 8.4 & 8.99 \\
\hline No.4 of Chinese red pine & $\mathrm{CP} 4$ & 1140 & 28 & semi-sunny & 1275 & 12.65 & 6.6 & 9.17 \\
\hline No. 5 of Chinese red pine & CP5 & 1120 & 23 & semi-sunny & 1425 & 8.72 & 7.9 & 6.67 \\
\hline No.1 of mixed forest ${ }^{b}$ & MF1 & 1060 & 35 & shady & 1150 & 11.98 & 9.4 & 7.75 \\
\hline No. 2 of mixed forest & MF2 & 1110 & 18 & semi-sunny & 1600 & 10.80 & 7.4 & 6.55 \\
\hline No.3 of mixed forest & MF3 & 1150 & 33 & semi-shady & 1625 & 9.40 & 8.0 & 5.37 \\
\hline No.4 of mixed forest & MF4 & 1060 & 32 & shady & 2125 & 9.63 & 7.8 & 4 \\
\hline No.5 of mixed forest & MF5 & 1130 & 27 & shady & 3075 & 10.31 & 8.3 & 5.89 \\
\hline No.1 of Grassland & GL1 & 950 & 21 & shady & - & - & - & - \\
\hline No.2 of Grassland & GL2 & 960 & 24 & semi-shady & - & - & - & - \\
\hline No.3 of Grassland & GL3 & 1010 & 40 & sunny & - & - & - & - \\
\hline No.4 of Grassland & GL4 & 990 & 22 & semi-shady & - & - & - & - \\
\hline No.5 of Grassland & GL5 & 970 & 24 & semi-sunny & - & - & - & - \\
\hline
\end{tabular}

${ }^{a} \mathrm{DBH}$, diameter at breast height. ${ }^{\mathrm{b}}$ Mixed forest included a mixture of black locust (Robinia pseudoacacia L.) and Chinese red pine (Pinus tabulaeformis Carr.). The data of the stand density, average $\mathrm{DBH}$, average tree height, average crown height, and average crown area came from the field surveys and measurements 


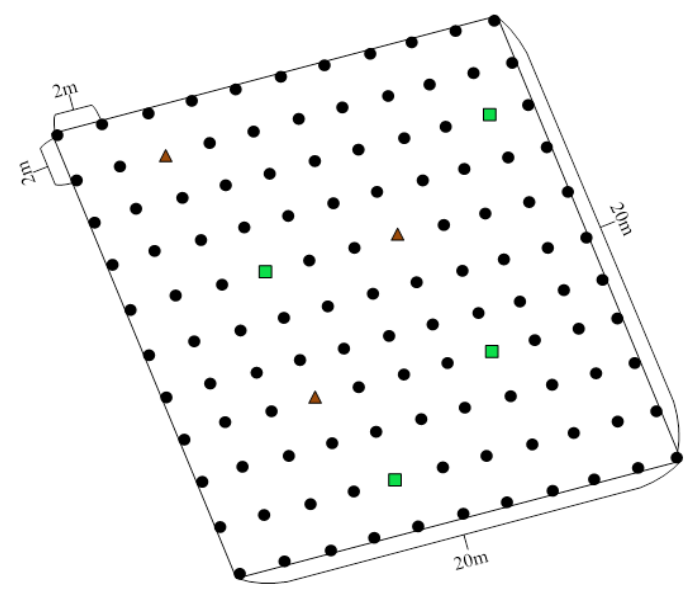

Figure 3. Schematic diagram of soil moisture sampling positions. In the diagram, the dots indicate the sampling points, the triangles indicate large rocks, and the squares indicate stout roots. Because the TDR probe could not be inserted into the soil at the correct angle, no soil moisture samples were collected in the positions with obstacles

\section{Results}

\section{Comparison of vegetation characteristics}

The major biological and soil physicochemical characteristics of the investigated plots are summarized in Table 2. The leaf area and transpiration of trees in the upper layer, and herbaceous plant diversity in the understory had different relationships with soil moisture and nutrients in the four types of stand. The LAI and transpiration rate trends of monoculture Robinia pseudoacacia L. and Pinus tabulaeformis Carr. followed the opposite pattern (Fig. 4A). The maximum LAI of pure Robinia pseudoacacia L. was larger than that of both pure Pinus tabulaeformis Carr. and mixed forests. The transpiration rate of the mixed forest was generally greater than that of the two pure species.

Table 2. The average value of each indicator

\begin{tabular}{|c|c|c|c|c|}
\hline Stand and soil characteristics & Black locust & $\begin{array}{c}\text { Chinese red } \\
\text { pine }\end{array}$ & Mixed forest & Grassland \\
\hline Canopy density & $0.59 \pm 0.15^{\mathrm{k}}$ & $0.68 \pm 0.09$ & $0.71 \pm 0.10$ & - \\
\hline $\mathrm{LAI}^{\mathrm{a}}$ & $2.32 \pm 1.23$ & $1.95 \pm 0.22$ & $2.04 \pm 0.49$ & - \\
\hline Transpiration rate $\left(\mathrm{g} \cdot \mathrm{m}^{-2} \cdot \mathrm{h}^{-1}\right)$ & $26.02 \pm 7.46$ & $27.91 \pm 9.88$ & $33.80 \pm 17.52$ & - \\
\hline Herb- $H^{\prime} \mathrm{b}$ & $1.80 \pm 0.21$ & $1.84 \pm 0.22$ & $1.57 \pm 0.49$ & $2.06 \pm 0.25$ \\
\hline Herb- $D^{\mathrm{c}}$ & $0.79 \pm 0.05$ & $0.79 \pm 0.04$ & $0.70 \pm 0.11$ & $0.85 \pm 0.04$ \\
\hline Herb- $J$ d & $0.86 \pm 0.03$ & $0.84 \pm 0.02$ & $0.83 \pm 0.08$ & $0.89 \pm 0.03$ \\
\hline Soil volumetric moisture content $(\%)$ & $12.80 \pm 4.58$ & $11.97 \pm 1.48$ & $6.75 \pm 1.38$ & $26.97 \pm 2.59$ \\
\hline $\operatorname{SOM}^{\mathrm{e}}\left(\mathrm{g} \cdot \mathrm{kg}^{-1}\right)$ & $11.23 \pm 2.68$ & $9.10 \pm 1.97$ & $10.22 \pm 1.43$ & $14.30 \pm 5.07$ \\
\hline $\mathrm{TN}^{\mathbf{f}}\left(\mathrm{g} \cdot \mathrm{kg}^{-1}\right)$ & $0.67 \pm 0.20$ & $0.65 \pm 0.25$ & $0.38 \pm 0.08$ & $0.43 \pm 0.13$ \\
\hline $\mathrm{TP}^{\mathrm{g}}\left(\mathrm{g} \cdot \mathrm{kg}^{-1}\right)$ & $0.64 \pm 0.14$ & $0.64 \pm 0.13$ & $0.53 \pm 0.06$ & $0.62 \pm 0.07$ \\
\hline $\mathrm{NH}_{3}-\mathrm{N}^{\mathbf{h}}\left(\mathrm{mg} \cdot \mathrm{kg}^{-1}\right)$ & $19.87 \pm 6.53$ & $22.68 \pm 5.92$ & $25.93 \pm 3.35$ & $17.43 \pm 5.38$ \\
\hline $\mathrm{NO}_{3}-\mathrm{N}^{\mathrm{i}}\left(\mathrm{mg} \cdot \mathrm{kg}^{-1}\right)$ & $10.65 \pm 4.97$ & $6.79 \pm 1.48$ & $9.13 \pm 2.87$ & $12.49 \pm 7.20$ \\
\hline $\mathrm{AP}^{\mathbf{j}}\left(\mathrm{mg} \cdot \mathrm{kg}^{-1}\right)$ & $35.52 \pm 7.96$ & $38.07 \pm 3.71$ & $45.96 \pm 7.88$ & $40.43 \pm 12.75$ \\
\hline
\end{tabular}

${ }^{\mathrm{a}}$ LAI, leaf area index. ${ }^{\mathrm{b}}$ Herb- $H^{\prime}$, Shannon-Wiener index value for the herb. ${ }^{\mathrm{c}}$ Herb- $D$, Simpson's diversity index value for the herb. ${ }^{\mathrm{d}}$ Herb- $J$, Pielou index value for the herb. ${ }^{\mathrm{e}} \mathrm{SOM}$, soil organic matter. ${ }^{\mathrm{f}} \mathrm{TN}$, total nitrogen. ${ }^{\mathrm{g}} \mathrm{TP}$, total phosphorus. ${ }^{\mathrm{h}} \mathrm{NH}_{3}-\mathrm{N}$, ammonia-nitrogen. ${ }^{\mathrm{i}} \mathrm{NO}_{3}-\mathrm{N}$, nitrate-nitrogen. ${ }^{\mathrm{j}} \mathrm{AP}$, available phosphorus. ${ }^{\mathrm{k}}$ The data in the table was presented in the forms of 'mean \pm variance' 


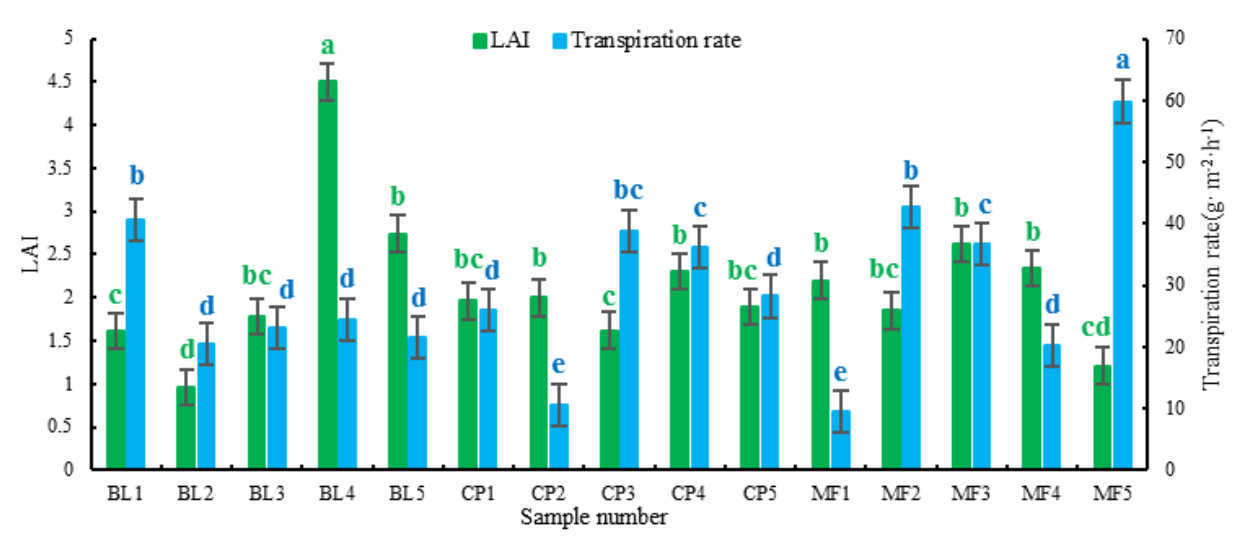

A

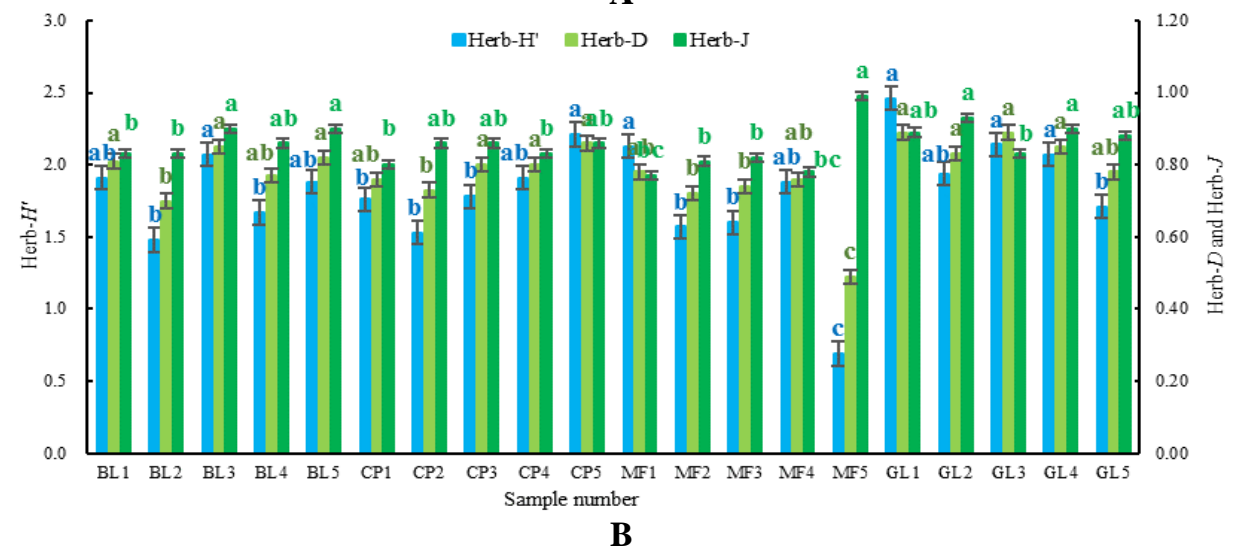

Figure 4. The vegetation characteristics of the different stands. (A) LAI and transpiration rate.

(B) The herbaceous diversity indexes. Note: LAI, leaf area index; Herb-H', Shannon-Wiener index of the herb; Herb-D, Simpson's index of the herb; Herb-J, Pielou index of the herb. Note:

BL1, 2, 3, 4, and 5 was abbreviation of No.1, 2, 3, 4, and 5 of black locust sample plots; CP 1, 2, 3, 4, and 5 was abbreviation of No.1, 2, 3, 4, and 5 of Chinese red pine sample plots; MF 1, 2, 3, 4, and 5 was abbreviation of No.1, 2, 3, 4, and 5 of mixed forest sample plots; and GL 1, 2, 3, 4, and 5 was abbreviation of No.1, 2, 3, 4, and 5 of Grassland sample plots in the figure and similarly hereinafter. The error bars are representing for standard error plus or minus. Different lowercase letters, such as $a, b, c, d$, and $e$, indicated $P<0.05$ in the same series of variables, through significance testing

In the understory of the different vegetation plots (Fig. 4B), the herbaceous Shannon-Wiener index values under Robinia pseudoacacia L. were higher than those under Pinus tabulaeformis Carr. and mixed forests, but lower than the pure grassland. The herbaceous Shannon-Wiener index and Simpson's index of all vegetation types displayed a similar trend, and were positively related to each other. In terms of the magnitude of the diversity indexes, the sample plots with trees were significantly lower than the monoculture grassland. The mixed forest had the lowest range of index values.

\section{Topsoil moisture heterogeneity}

The correlations between average topsoil moisture and slope were not very strong, with the curves of their variation in the sample plots being irregular (Fig. 5). The results showed large differences in soil moisture, with the average soil moisture in the sample plots for the three types of overstory trees being lower than that of pure grassland. 

-802 -

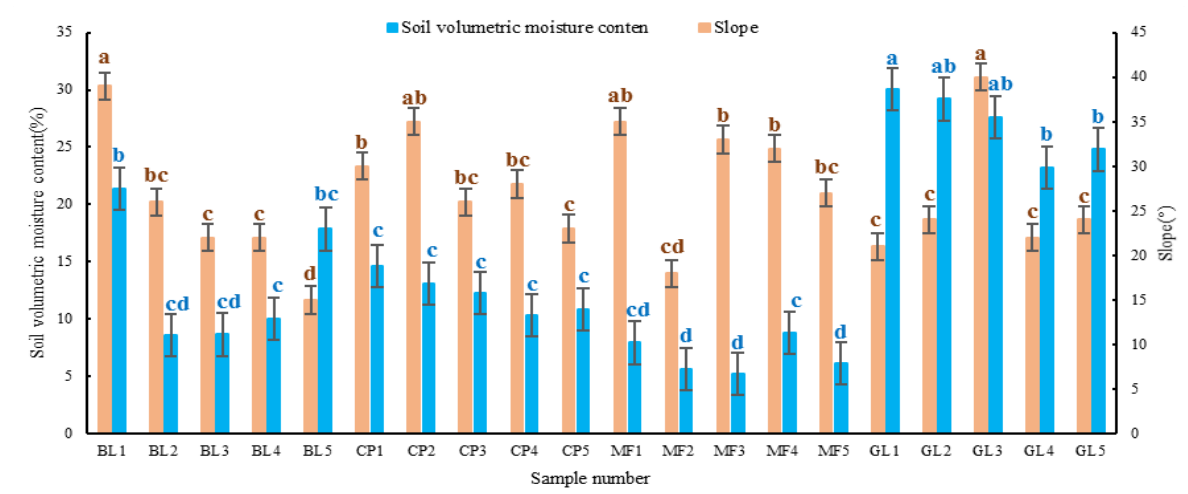

Figure 5. The topsoil volumetric moisture content in relation to the slope for all samples. Note: The error bars were representing for standard error plus or minus. Different lowercase letters, such as $a, b$, and $c$ indicated $P<0.05$ in the same series of variables, through significance testing

The moisture data basically followed a normal distribution, and the spatial heterogeneity of the topsoil moisture was demonstrated through a kriging interpolation (Krige, 1966). The nugget effects were residual in all the ordinary kriging cases, the values of which showed moderate variations, with coefficients of variation $(C V s)$ of $11.78 \%, 10.36 \%, 9.82 \%$, and $5.44 \%$ for the data in Figures 6 to 9, respectively. The random variances $\left(C_{0}\right)$ accounted for nearly $8 \%$ of the total variances $\left(C_{0}+C\right)$ in the topsoil moisture values of the different vegetation types, indicating that there were strong spatial autocorrelations of soil moisture values within $15 \mathrm{~m}$, and the values of $R^{2}$ ranged from 0.752 to 0.793 . The values of these parameters demonstrated that the variances were minimal, and the number of samples was sufficient to assess the spatial variability of topsoil moisture. Additionally, the $y$ coordinate values were small, which meant that the topsoil moisture content of the soil samples was small below the slope and large on the slope.

The range of the topsoil moisture values for all species was from 0 to $47.9 \%$. In the figures (Figs. from 6 to 9), a bluish color indicates a high moisture content and a greenish color indicates a low moisture content. The topsoil moisture distributions of pure Robinia pseudoacacia L. are shown in Fig. 6, with a value ranging from $5.1 \%$ to $26.6 \%$. In addition to terrain and vegetation factors, the distribution of soil moisture was dependent on the canopy LAI and understory diversity. In the plots with high LAI values and strong herbaceous diversity, the soil volumetric moisture content in the surface layer was large. The soil moisture content in the pure Pinus tabulaeformis Carr. plots ranged from $6.2 \%$ to $20.3 \%$ (Fig. 7). According to the topographical and forest plantation characteristics in the sample plots, some of the coniferous forest plots (e.g., CP1) were located in semi-sunny areas, in which the LAI values and herbaceous diversity were higher than in the shady region. The distribution of topsoil moisture was positively correlated with plant factors. A high LAI value indicated that there was a large amount of soil water in the corresponding plot. The topsoil moisture distribution of the mixed forests was slightly unusual (Fig. 8). It had smallest range of the four vegetation types, with values between $2.6 \%$ and $12.7 \%$. The aspects of the three plots were semi-sunny, semi-shady, and shady, respectively, and were not significantly correlated with the soil water content. The soil moisture content had negative relationships with the slope, LAI, Shannon-Wiener index, and Simpson's index. 

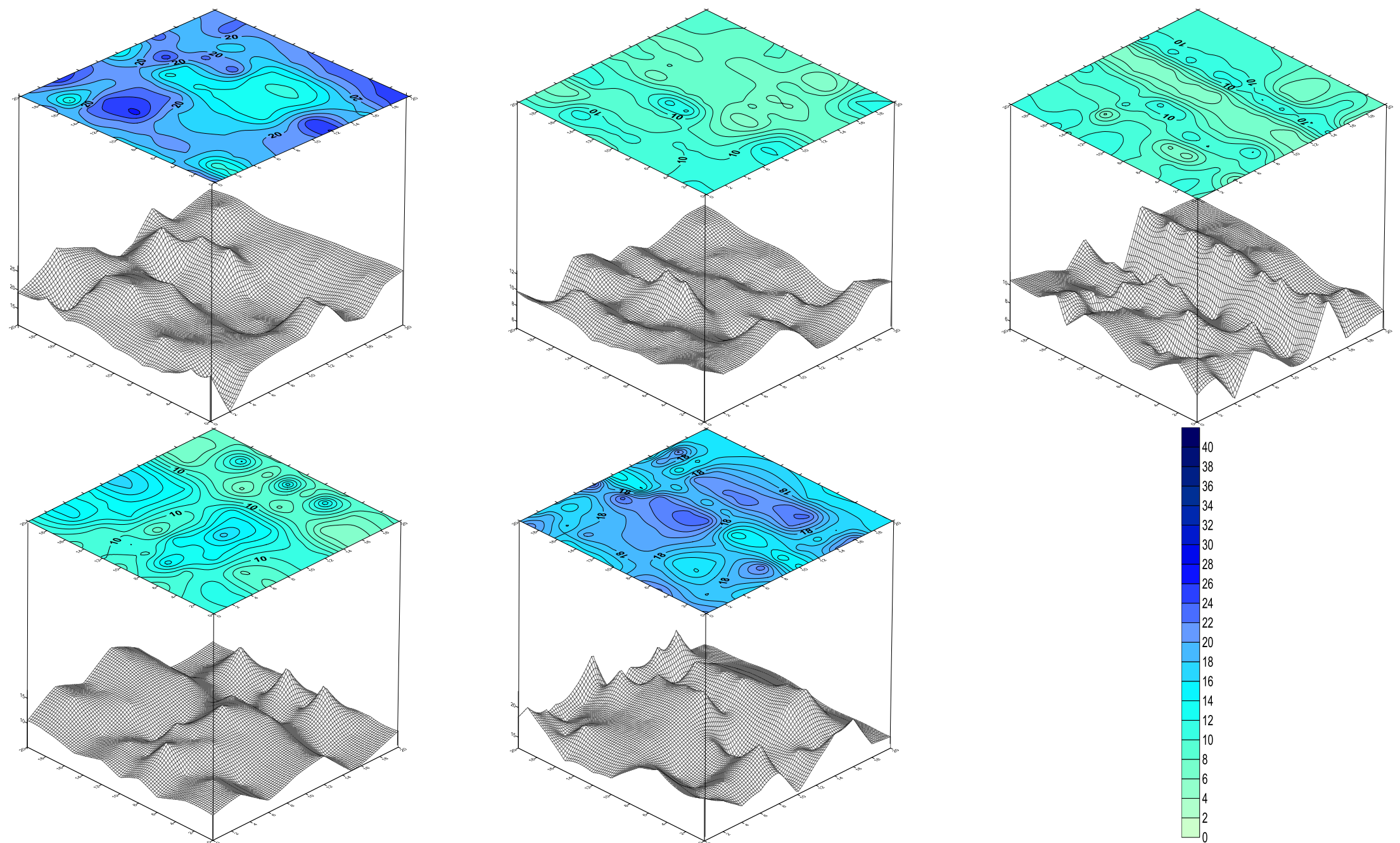

Figure 6. The topsoil volumetric moisture content distribution in Robinia pseudoacacia L. plots. (A) BL1; (B) BL2; (C) BL3; (D) BL4; (E) BL5

APPLIED ECOLOGY AND ENVIRONMENTAL RESEARCH 19(1):795-815.

http://www.aloki.hu • ISSN 15891623 (Print) $\bullet$ ISSN1785 0037 (Online)

DOI: http://dx.doi.org/10.15666/aeer/1901_795815

(c) 2021, ALÖKI Kft., Budapest, Hungary 

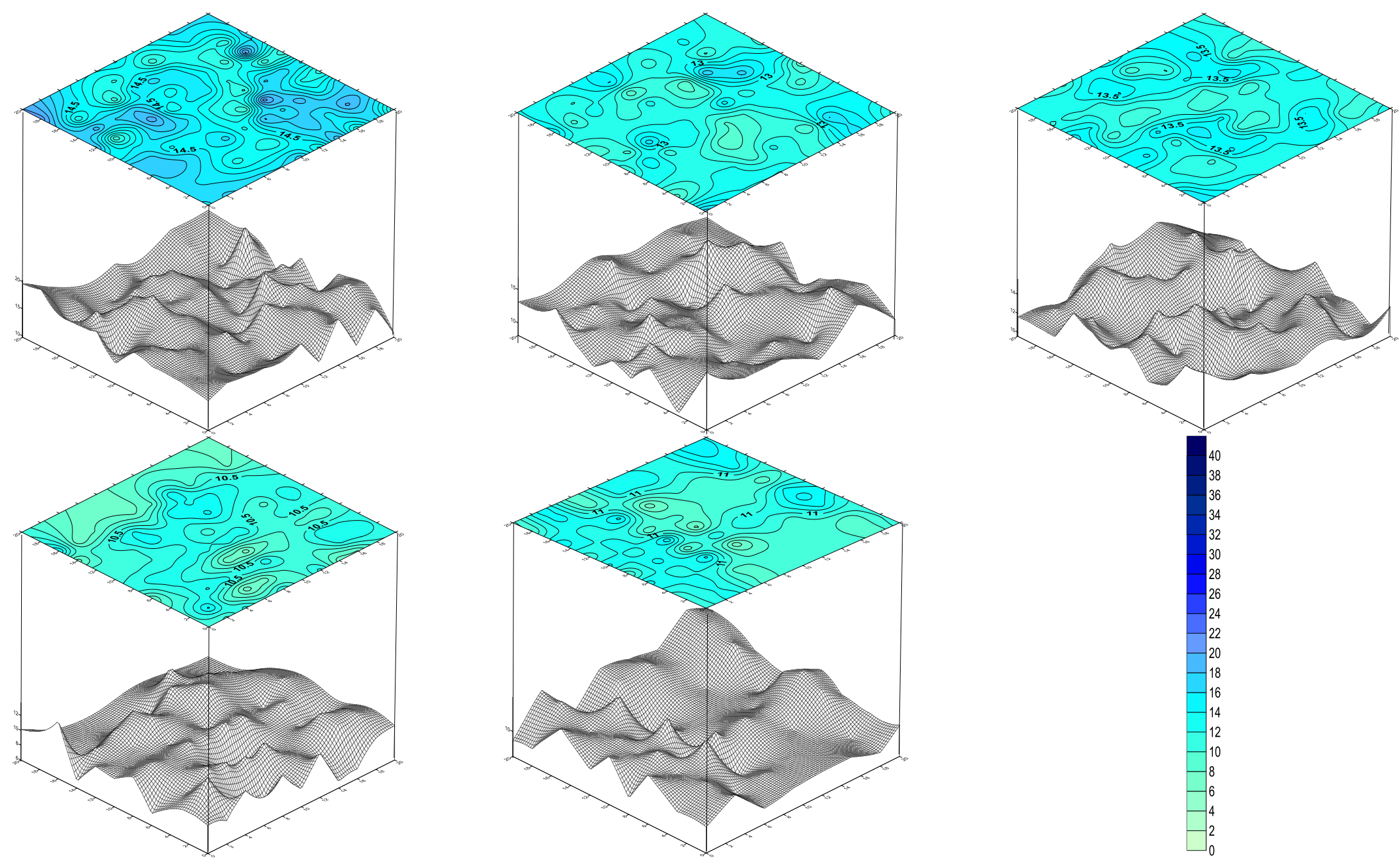

Figure 7. The topsoil volumetric moisture content distribution in Pinus tabulaeformis Carr. plots. (A) CP1; (B) CP2; (C) CP3; (D) CP4; (E) CP5

APPLIED ECOLOGY AND ENVIRONMENTAL RESEARCH 19(1):795-815.

http://www.aloki.hu • ISSN 15891623 (Print) $\bullet$ ISSN1785 0037 (Online)

DOI: http://dx.doi.org/10.15666/aeer/1901_795815

(c) 2021, ALÖKI Kft., Budapest, Hungary 

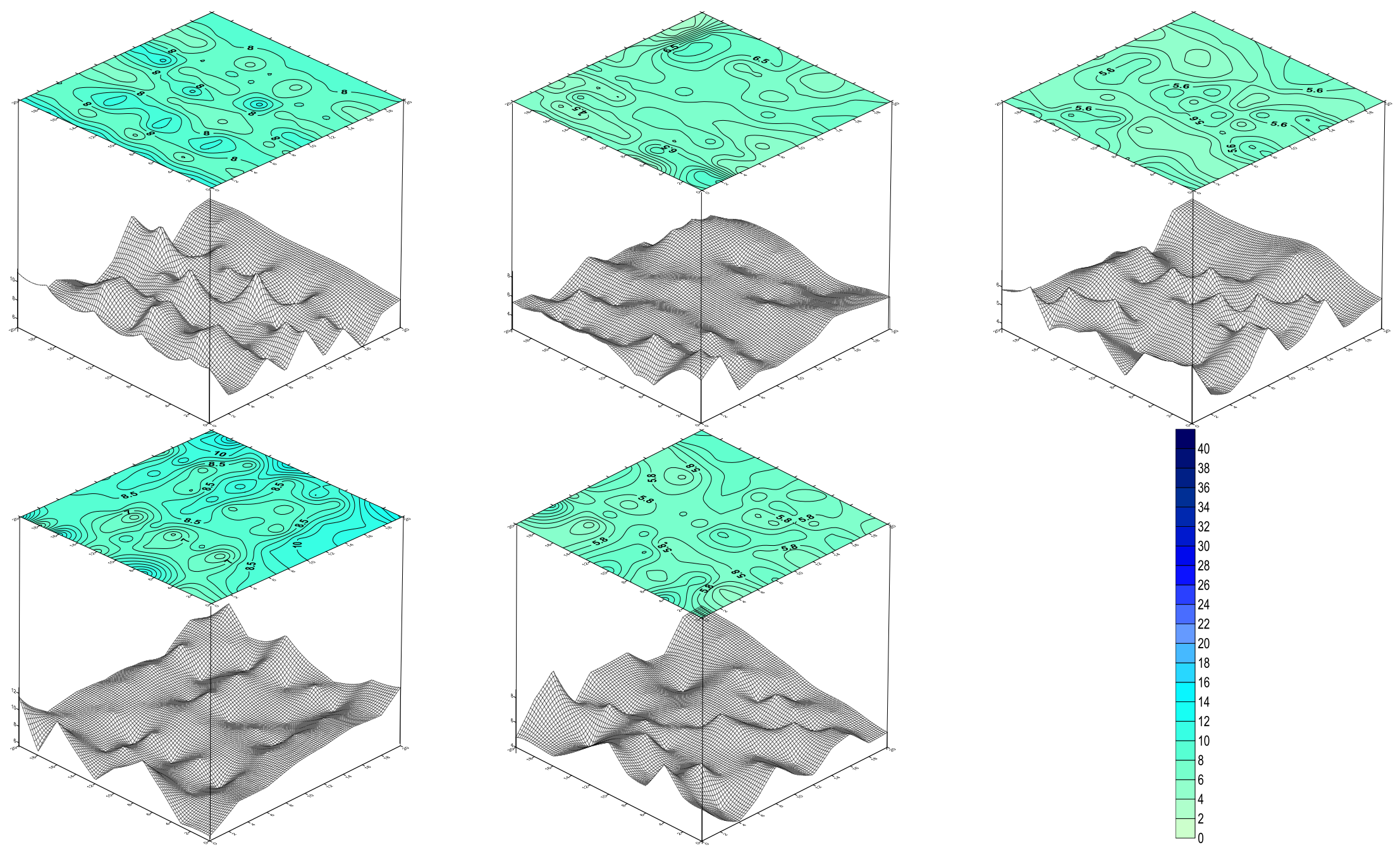

Figure 8. The topsoil volumetric moisture content distribution in mixed forest plots. (A) MF1; (B) MF2; (C) MF3; (D) MF4; (E) MF5

APPLIED ECOLOGY AND ENVIRONMENTAL RESEARCH 19(1):795-815.

http://www.aloki.hu • ISSN 15891623 (Print) • ISSN1785 0037 (Online)

DOI: http://dx.doi.org/10.15666/aeer/1901_795815

(c) 2021, ALÖKI Kft., Budapest, Hungary 

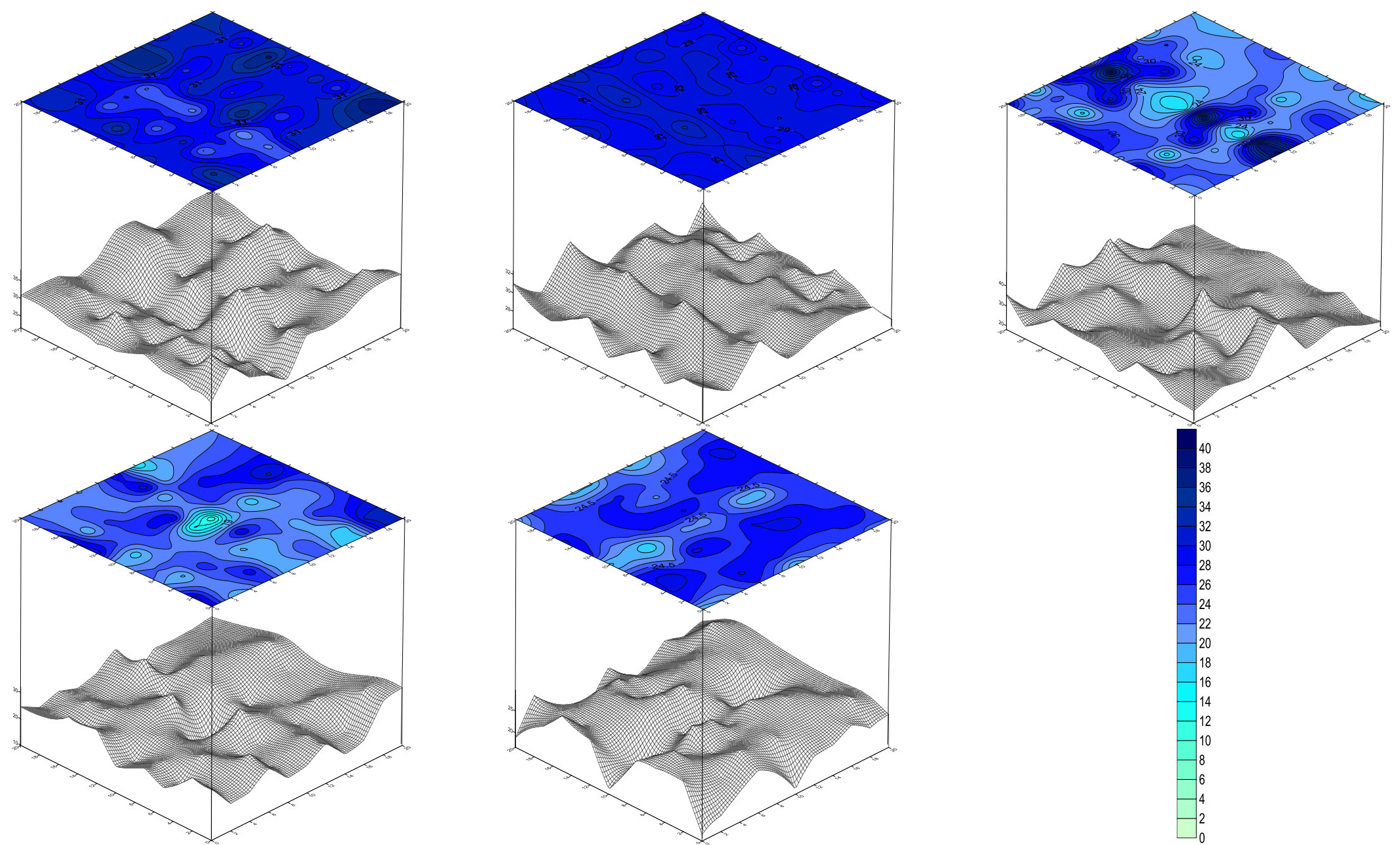

Figure 9. The topsoil volumetric moisture content distribution of grassland plots for reference. (A) GL1; (B) GL2; (C) GL3; (D) GL4; (E) GL5

APPLIED ECOLOGY AND ENVIRONMENTAL RESEARCH 19(1):795-815.

http://www.aloki.hu • ISSN 15891623 (Print) • ISSN1785 0037 (Online)

DOI: http://dx.doi.org/10.15666/aeer/1901_795815

(c) 2021, ALÖKI Kft., Budapest, Hungary 
Compared to the grassland (Fig. 9), the topsoil moisture content of both pure and mixed forests were significantly smaller under the canopies than in those areas with only a low herb coverage, most values of which were more than $15 \%$, with a maximum of $47.9 \%$. The values for the mixed forests had the smallest range of all the stands. From the three-dimensional models of the top soil water distribution (Figs. from 6 to 9), there was a large spatial heterogeneity of surface soil moisture in all four types of stand and the amplitude of the variations was different.

\section{Changes of soil properties}

The soil properties are presented in Fig. 10, including soil SOM, TN, TP, $\mathrm{NH}_{3}-\mathrm{N}$, $\mathrm{NO}_{3}-\mathrm{N}$, and AP. The soil properties from the field sites were in correspondence with the plant and water conditions. The grassland plots had more SOM and less $\mathrm{NH}_{3}-\mathrm{N}$ than the other stands, and the pure Robinia pseudoacacia L. stands had more TN.

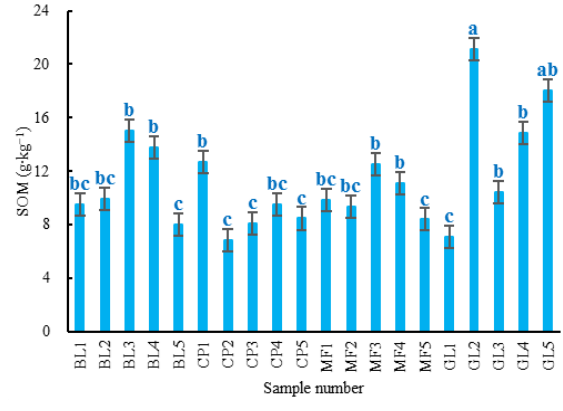

A
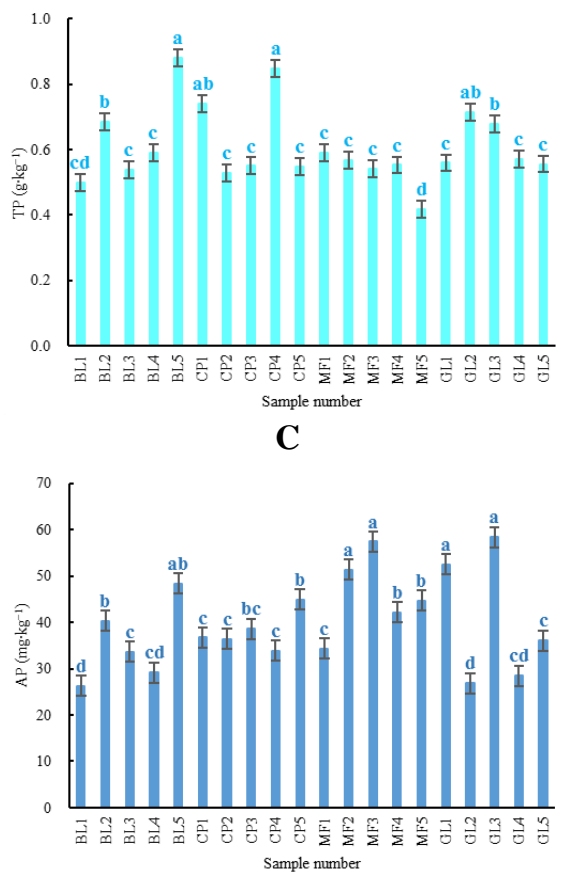

$\mathbf{E}$

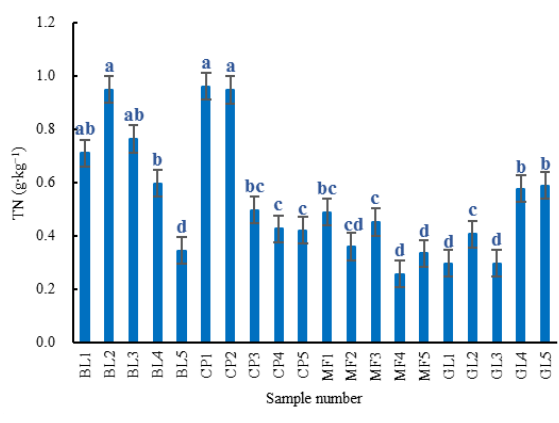

B

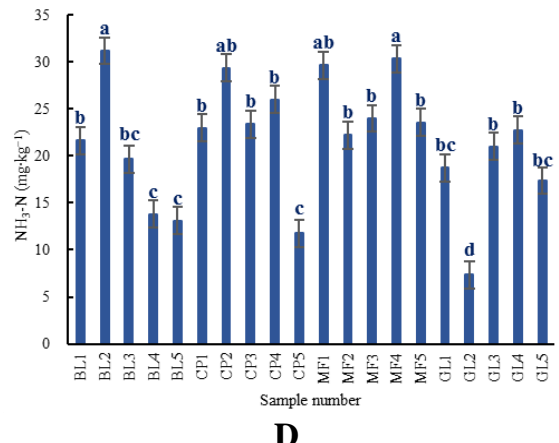

D

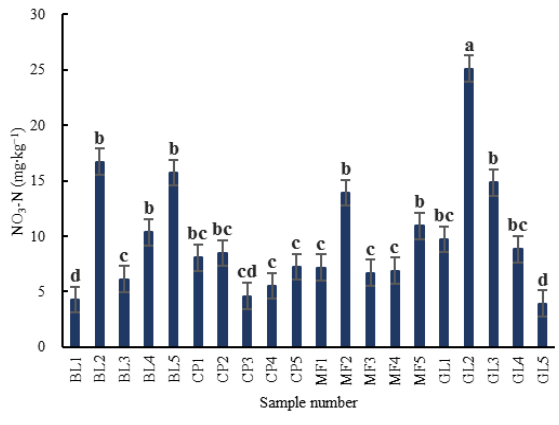

$\mathbf{F}$

Figure 10. The topsoil properties of the different sampling plots. (A) Soil organic matter (SOM).

(B) Total nitrogen (TN). (C) Total phosphorus (TP). (D) Ammonia-nitrogen $\left(\mathrm{NH}_{3}-\mathrm{N}\right)$. (E)

Available phosphorus $(A P) .(F)$ Nitrate-nitrogen $\left(\mathrm{NO}_{3}-\mathrm{N}\right)$. Note: The error bars were representing for standard error plus or minus. Different lowercase letters, such as $a, b, c$, and $d$ indicated $P<0.05$ in the same series of variables, through significance testing 
Liang - Wei: Spatial heterogeneity of topsoil moisture and impact of vegetation factors on its distribution under pure and mixed black locust (Robinia pseudoacacia L.) and Chinese red pine (Pinus tabulaeformis Carr.) forests on the Loess Plateau in China $-808-$

\section{Relationships of topsoil moisture spatial heterogeneity with plant and soil properties}

After feature and geostatistical analyses, some of the important factors that impacted on the spatial heterogeneity of topsoil moisture were determined, including canopy density, LAI, three herbaceous diversity indexes, transpiration rate, and TN. Correlation coefficients were calculated to identify the associations among all the variables through a Pearson's correlation analysis, and the results for the three plantations are shown in Table 3.

Table 3. The results of a Pearson's correlation analysis for the three plantations

\begin{tabular}{|c|c|c|c|c|c|c|c|c|c|}
\hline Stand type & Index name & $\begin{array}{l}\text { Canopy } \\
\text { density }\end{array}$ & LAI & Herb- $H$ & , Herb-D & Herb-J & $\begin{array}{c}\text { Transpi- } \\
\text { ration rate }\end{array}$ & VCM & $\mathbf{T N}$ \\
\hline \multirow{8}{*}{$\begin{array}{c}\text { Robinia } \\
\text { pseudoacacia } \\
\text { L. }\end{array}$} & Canopy density & 1.000 & 0.411 & -0.385 & -0.275 & -0.167 & 0.047 & 0.689 & -0.576 \\
\hline & $\mathbf{L A I}^{\mathbf{c}}$ & & 1.000 & 0.581 & 0.687 & 0.765 & -0.105 & 0.584 & $-0.980^{* a}$ \\
\hline & Herb- $H^{\text {,d }}$ & & & 1.000 & $0.991^{* * \mathrm{~b}}$ & 0.644 & 0.308 & 0.287 & -0.465 \\
\hline & Herb- $D^{\mathrm{e}}$ & & & & 1.000 & 0.704 & 0.257 & 0.354 & -0.58 \\
\hline & Herb-J $f^{f}$ & & & & & 1.000 & -0.496 & -0.050 & -0.629 \\
\hline & $\begin{array}{c}\text { Transpiration } \\
\text { rate }\end{array}$ & & & & & & 1.000 & 0.626 & 0.028 \\
\hline & $\mathbf{V C M}^{\mathrm{g}}$ & & & & & & & 1.000 & -0.703 \\
\hline & $\mathbf{T N}^{\mathrm{h}}$ & & & & & & & & 1.000 \\
\hline \multirow{8}{*}{$\begin{array}{c}\text { Pinus } \\
\text { tabulaeformis } \\
\text { Carr. }\end{array}$} & Canopy density & 1.000 & 0.667 & -0.395 & -0.465 & 0.324 & -0.602 & 0.893 & 0.127 \\
\hline & LAI & & 1.000 & 0.270 & -0.060 & -0.388 & -0.147 & 0.504 & -0.062 \\
\hline & Herb- $H^{\prime}$ & & & 1.000 & 0.896 & -0.430 & 0.898 & -0.690 & -0.751 \\
\hline & Herb-D & & & & 1.000 & -0.026 & $0.986^{*}$ & -0.812 & -0.922 \\
\hline & Herb-J & & & & & 1.000 & -0.122 & 0.179 & -0.271 \\
\hline & $\begin{array}{c}\text { Transpiration } \\
\text { rate }\end{array}$ & & & & & & 1.000 & -0.893 & -0.845 \\
\hline & $\mathrm{VCM}$ & & & & & & & 1.000 & 0.560 \\
\hline & $\mathbf{T N}$ & & & & & & & & 1.000 \\
\hline \multirow{8}{*}{$\begin{array}{c}\text { Mixed } \\
\text { Robinia } \\
\text { pseudoacacia } \\
\text { L. and Pinus } \\
\text { tabulaeformis } \\
\text { Carr. forests }\end{array}$} & Canopy density & 1.000 & -0.869 & $-0.999^{*}$ & $-0.998^{* *}$ & 0.994 & 0.982 & 0.936 & -0.709 \\
\hline & LAI & & 1.000 & 0.854 & 0.875 & -0.810 & -0.947 & -0.987 & 0.965 \\
\hline & Herb- $H^{\prime}$ & & & 1.000 & $0.999^{*}$ & $-0.997^{*}$ & -0.975 & -0.925 & 0.687 \\
\hline & Herb-D & & & & 1.000 & -0.993 & -0.984 & -0.941 & 0.717 \\
\hline & Herb-J & & & & & 1.000 & 0.955 & 0.893 & -0.628 \\
\hline & $\begin{array}{c}\text { Transpiration } \\
\text { rate }\end{array}$ & & & & & & 1.000 & 0.986 & -0.830 \\
\hline & VCM & & & & & & & 1.000 & -0.911 \\
\hline & TN & & & & & & & & 1.000 \\
\hline
\end{tabular}

$\mathrm{a} *$, the correlation was significant at the 0.05 level (bilateral). ${ }^{\mathrm{b}} * *$, the correlation was significant at the 0.01 level (bilateral). ${ }^{\mathrm{c}}$ LAI, leaf area index. ${ }^{\mathrm{d}}$ Herb- $H^{\prime}$, Shannon-Wiener index value for the herb. ${ }^{\mathrm{e}}$ Herb- $D$, Simpson's index value for the herb. ${ }^{\mathrm{f}}$ Herb- $J$, Pielou index value for the herb. ${ }^{\mathrm{g}}$ VCM, Soil volumetric moisture content. ${ }^{\mathrm{h}} \mathrm{TN}$, total nitrogen

The LAI of Robinia pseudoacacia L. was negatively correlated with TN at the 0.05 level and the Shannon-Wiener index was positively correlated with the Simpson's index at the 0.01 level, with correlation coefficients of -0.980 and 0.991 , respectively. The 
Simpson's index of Pinus tabulaeformis Carr. was positively correlated with the transpiration rate at the 0.05 level, with a correlation coefficient of 0.986 . In the mixed forests, the canopy density had significantly negative correlations with the Shannon-Wiener index and Simpson's index, with correlation coefficients of -0.999 (significant at the 0.05 level) and -0.998 (significant at the 0.01 level), respectively. The Shannon-Wiener index was negatively correlated with the Pielou index, which had a correlation coefficient of -0.997 (significant at the 0.05 level). The relationships between the above indicators demonstrated that the influences of the overstory and understory flora on soil moisture were significant.

The connections among plantations, topsoil water, and soil properties were calculated quantitatively using their correlation coefficients. Most coefficients were greater than 0.5 , indicating that the overstory and understory properties were closely correlated to the topsoil moisture and then influenced its spatial heterogeneity. In particular, canopy density, LAI, transpiration rate, and $\mathrm{TN}$ affected the soil water significantly in all three kinds of forest stand. When the different tree species were compared, the impacts of these factors in the mixed forests presented stronger correlations, with all correlation coefficients greater than 0.89. Although the significance of the correlation analysis results was not very strong, which reduced their credibility, the quantitative relationships between plant factors, topsoil moisture, and nutrients were still of interest and provided some evidence for the complex relationships between the upper forest canopy, herbs under the forests, topsoil moisture, and soil nutrients.

\section{Discussion}

\section{Biotic factors}

Although the spatial heterogeneity of topsoil moisture is sensitive to biotic factors, such as the canopy density, LAI, herbaceous diversity, or transpiration rate (Paluch and Gruba, 2012; Von Arx et al., 2013; Gebrekiros and Tessema, 2018), no clear conclusions have emerged from studies of different vegetation stands in the Loess Plateau (Hu et al., 2019). This is most likely because the factors controlling the spatial heterogeneity of soil water change with species composition or forest structure (Barksdale and Anderson, 2015). In the present study, the LAI, Shannon-Wiener index, and transpiration rate significantly affected the values and distributions of topsoil moisture. Similar results have been reported elsewhere. For example, transpiration can became limited by the available soil moisture in the surface and middle-layer soils (Meerveld and Mcdonnell, 2006), and canopy characteristics and plant diversity have been shown to be significantly and positively correlated with moisture in the topsoil (Deng et al., 2016). These findings suggest that the LAI and herbaceous diversity were likely related to the spatial heterogeneity of topsoil water more closely than the other factors (Manea and Leishman, 2014; Singh et al., 2017).

The results suggested a positive correlation between the LAI and transpiration in Robinia pseudoacacia L., as a representative broad-leaved tree species, and an insignificant negative correlation in Pinus tabulaeformis Carr., which is a typical coniferous species in the region. When the two species formed mixed forests, the negative correlations of the LAI and transpiration were significantly enhanced and the gradient of the plotted relationship between these variables also increased slightly. The stands with lower LAI values and herbaceous diversity had a lower topsoil moisture 
Liang - Wei: Spatial heterogeneity of topsoil moisture and impact of vegetation factors on its distribution under pure and mixed

content and less spatial heterogeneity. In the Pinus tabulaeformis Carr. and mixed forest plots there was a low moisture content in uphill locations and a high moisture content in downhill locations. The LAI was therefore an important variable that significantly affected the spatial heterogeneity of topsoil water. In addition, the topsoil volumetric moisture content had a close relationship with the understory vegetation (Nijland et al., 2010; Özkan and Gökbulak, 2017). The larger the LAI, the smaller the variation of the soil water distribution, except in the pure Pinus tabulaeformis Carr. forest. Topsoil moisture was not only affected by the herbs or lower growing vegetation but also significantly affected by the tall trees.

There are three processes that could potentially explain this. First, canopy interception and plant water uptake made different contributions to soil water conservation. In our study, trees with understory herbs absorbed more topsoil water than the monoculture grassland, indicating that canopy interception was less than the water consumption of trees. In the tree plots, a larger canopy LAI in the pure plantations often indicated a high soil moisture content, while in contrast, in the mixed forests it indicated that soil moisture was low. Different tree species and their configurations in the same stand determined the LAI and plant growth, which could then increase or decrease the topsoil moisture content and its distribution. Second, the overstory and understory vegetation competed for water use. The understory diversity significantly influenced the soil water content in the surface layer. A large diversity led to significantly less topsoil water and a very even distribution in the pure coniferous and mixed forests, while in the pure broad-leaved Robinia pseudoacacia L. forests it led to enhanced topsoil moisture that was less evenly distributed. Third, LAI and herbaceous diversity impacted differently on the soil moisture, with positive benefits in the broad-leaved forests and a negative impact in the other forest types. Hence, these two dominant biotic factors promoted each other synergistically in the typical broad-leaved forests, but their effects were limited in the coniferous and mixed forests in the area. Mixed forests had the lowest soil moisture content among the four types of plots, possibly because the higher stand densities had negative effects on the undergrowth herbs.

\section{Abiotic factors}

Many previous studies have reported that abiotic factors affect the soil water content and its spatial distribution (Gebrekiros and Tessema, 2018), and some have focused on the spatial heterogeneity of soil moisture (Ronda et al., 2002; Liu et al., 2018). Soil moisture is also closely related to slope and some other topographic variables (Frindte et al., 2019), but few studies have investigated the relative and interactional contributions of biotic and abiotic factors in the overstory and understory flora to the spatial variation of soil moisture. Here, topography and topsoil moisture were among the abiotic factors considered, together with the corresponding soil properties (e.g., SOM, TN, and TP), which were commonly used indicators in previous studies (Jose and Romero Diaz, 2010). Topographic and plant factors jointly determined the distribution of soil water and nutrients. Topography typically affects the distribution of many soil properties (Endara and Jaramillo, 2011). In this study, we used a feature and correlational analysis method to screen out the classes of abiotic factors.

Topographic variables including slope, aspect, and elevation were not significantly related to the spatial distribution of soil water in the different stands (Fig. 5). Among the six variables related to soil properties, only TN significantly and negatively impacted on the spatial distribution of topsoil moisture, especially in the pure Robinia 
pseudoacacia L. and mixed forest plots, with a similar result reported by (Wang et al., 2015). According to the three-dimensional models of the topsoil water distribution, a smaller TN resulted in a larger variation of the water content. Based on this, we inferred that some abiotic factors represented by a TN enrichment in the topsoil might reduce the retention of topsoil water. At the same time, the correlations with biotic factors, such as the canopy LAI and Shannon-Wiener index for example, could be considered to improve the topsoil moisture content. Thus, the distribution of topsoil moisture was likely to be correlated to TN, which influenced the soil moisture content and the growth of overstory and understory flora. The variations of the spatial heterogeneity in the stands with an overstory canopy were significantly greater than those with only low growing herbs. The soil properties and water content of the vegetation displayed significant variations, so that the effect of topsoil moisture on spatial heterogeneity was limited.

\section{Implications of the topsoil moisture spatial heterogeneity}

Spatial heterogeneity in topsoil moisture is very helpful for determining the optimal sample-plot size to accurately estimate the soil moisture content (Martínez-Murillo et al., 2017). Compared with a single point sampling method, an understanding of the soil water distribution and its spatial heterogeneity in a standard sampling plot of $20 \times 20 \mathrm{~m}$ would enhance the reliability of the relationships between soil moisture and other factors (Evans and Love, 1957). The observed autocorrelation in topsoil moisture content values over a short range $(15 \mathrm{~m})$ suggested that the scale of a standard sample was appropriate to avoid the influence of autocorrelation. On the other hand, the spatial heterogeneity was correlated with not only the scale but also the direction (Rossi et al., 1992), including slope position (Figs. 6, 7, and 8), which probably had an influence on the soil water. Generally, there was a low moisture content in uphill locations and a high moisture content in downhill locations. Because the different biotic and abiotic factors had a combined impact on the moisture content, both scale and direction should be studied when exploring the spatial distributions of these or other factors in the future.

The spatial heterogeneity of topsoil moisture is helpful for understanding underlying ecological processes, such as the competition for water between trees and herbs, mechanisms of species coexistence and the response of plants to environmental heterogeneity (Keitt et al., 2002). For example, the stands containing trees and understory herbs consumed more soil water than the grassland monoculture, and therefore canopy interception was less than the water consumption of trees. The overstory and understory vegetation competed for water, and the soil properties and water content of the vegetation displayed significant variations, which affected the spatial heterogeneity of topsoil moisture. Significantly, the spatial patterns of soil moisture in different plantations were mainly determined by the stand structure in the overstory and understory flora. Therefore, understanding the principles that control the spatial distribution of topsoil moisture and the effects of site conditions on the distribution of water might provide a valuable reference for forest management (Montes et al., 2008; Liu et al., 2018).

\section{Conclusions}

The main factors controlling the spatial patterns of soil moisture were the canopy LAI, the herbaceous Shannon-Wiener and Simpson's indexes for plants growing under 
the forest canopy, and TN. Additionally, the dependency of the soil water content on the tree species and the forest composition cannot be ignored. The lowest moisture content was found in uphill locations and the highest moisture content was found in downhill locations. The larger canopy LAI of the pure plantations often indicated a high soil moisture content, with the opposite situation apparent in the mixed forest. Combined with the herbaceous diversity, the overstory and understory factors impacted on the soil moisture positively in the pure Robinia pseudoacacia L. plots and negatively in the pure Pinus tabulaeformis Carr. and mixed forest plots. This study revealed the spatial heterogeneity and interactions between the overstory and understory factors of various typical vegetation types in the semiarid Loess Plateau. Moreover, the next experimental design should take more sample plots and a long-term observation to verify the results in the future. Exploring these relationships and understanding the factors controlling the spatial variation of topsoil moisture will promote the comprehensive utilization of soil water, the optimization of overstory and understory vegetation, and improve the growth of vegetation in the Loess Plateau.

Acknowledgements. The study was supported by the National Natural Science Foundation of China (31971644 and 31901365), Scientific and Technological Innovation Programs of Higher Education Institutions in Shanxi (2019L0394), the Shanxi Provincial Outstanding Doctoral Program for Incentive Funds for Scientific Research Projects (SXYBKY2018032), and the Fund for Introduced Talents for Shanxi Agricultural University (2018YJ09). We would like to thank our colleagues for their comments on this paper.

\section{REFERENCES}

[1] Ahmad, S., Liu, H., Beyer, F., Klöve, B., Lennartz, B. (2020): Spatial heterogeneity of soil properties in relation to microtopography in a non-tidal rewetted coastal mire. Mires \& Peat 26(4): 1-18.

[2] Barksdale, W. F., Anderson, C. J. (2015): The influence of land use on forest structure, species composition, and soil conditions in headwater-slope wetlands of coastal Alabama, USA. - International Journal of Biodiversity Science Ecosystem Services \& Management 11: 61-70.

[3] Brzostek, E. R., Dragoni, D., Schmid, H. P., Rahman, A. F., Sims, D., Wayson, C. A., Johnson, D. J., Phillips, R. P. (2014): Chronic water stress reduces tree growth and the carbon sink of deciduous hardwood forests. - Global Change Biology 20: 2531-2539.

[4] Daniel, J. A., Ramaraju, K., Rameshkumar, A. (2019): Comparative studies of mymarid diversity from three different zones of paddy ecosystem in Tamil Nadu, India. - Entomon 44(3): 173-182.

[5] Deng, L., Wang, K. B., Li, J. P., Zhao, G. W., Shangguan, Z. P. (2016): Effect of soil moisture and atmospheric humidity on both plant productivity and diversity of native grasslands across the Loess Plateau, China. - Ecological Engineering 94: 525-531.

[6] Eldridge, D. J., Travers, S. K., Val, J., Wang, J. T., Liu, H., Singh, B. K., Delgado-Baquerizo, M. (2019): Grazing regulates the spatial heterogeneity of soil microbial communities within ecological networks. - Ecosystems 23: 932-942.

[7] Endara, M. J., Jaramillo, J. L. (2011): The influence of microtopography and soil properties on the distribution of the speciose genus of trees, Inga (Fabaceae: Mimosoidea), in Ecuadorian Amazonia. - Biotropica 43(2): 157-164.

[8] Evans, R. A., Love, R. M. (1957): The step-point method of sampling-a practical tool in range research. - Journal of Range Management Archives 10: 208-212. 
[9] Farley, R. A., Fitter, A. H. (1999): Temporal and spatial variation in soil resources in a deciduous woodland. - Journal of Ecology 87: 688-696.

[10] Frindte, K., Pape, R., Werner, K., Löffler, J., Knief, C. (2019): Temperature and soil moisture control microbial community composition in an arctic-alpine ecosystem along elevational and micro-topographic gradients. - The ISME Journal 13: 2031-2043.

[11] Gebrekiros, M. G., Tessema, Z. K. (2018): Effect of Senna obtusifolia (L.) invasion on herbaceous vegetation and soil properties of rangelands in the western Tigray, northern Ethiopia. - Ecological Processes 7(1): 9.

[12] Grime, J. P. (1994): The role of plasticity in exploiting environmental heterogeneity. - In: Caldwell, M. M., Pearcy, R. W. (eds.) Exploitation of environmental heterogenty by plants, pp. 1-19.

[13] Hu, Y. F., Dao, R. N., Hu, Y. (2019): Vegetation change and driving factors: contribution analysis in the Loess Plateau of China during 2000-2015. - Sustainability 11(5): 1320.

[14] Jose, D. R. S., Romero Diaz, A. (2010): The relationships among biotic and abiotic factors as control soil degradation processes along a Mediterranean pluviometric gradient. - Geomorphology 12: 1399D.

[15] Keitt, T. H., Bjørnstad, O. N., Dixon, P. M., Citron-Pousty, S. (2002): Accounting for spatial pattern when modeling organism-environment interactions. - Ecography 25: 616-625.

[16] Krige, D. (1966): Two-dimensional weighted moving average trend surfaces for ore-evaluation. - Journal of the South African Institute of Mining and Metallurgy 66: 13-38.

[17] Li, S., Liang, W., Fu, B. J., Lu, Y. H., Fu, S. Y., Wang, S., Su, H. M. (2016): Vegetation changes in recent large-scale ecological restoration projects and subsequent impact on water resources in China's Loess Plateau. - Science of the Total Environment 569-570: 1032-1039.

[18] Li, T. Z., Tian, S., Xiang, Y. L., Fang, Y., Yan, E. R. (2018): Species, functional, structural diversity of typical plant communities and their responses to environmental factors in Miao Archipelago, China. - The Journal of Applied Ecology 29: 343-351.

[19] Liu, Z. L., Jiang, F., Zhu, Y., Li, F., Jin, G. Z. (2018): Spatial heterogeneity of leaf area index in a temperate old-growth forest: Spatial autocorrelation dominates over biotic and abiotic factors. - Science of the Total Environment 634: 287-295.

[20] Ma, H., Zhu, Q. K., Zhao, W. J. (2020): Soil water response to precipitation in different micro-topographies on the semi-arid Loess Plateau, China. - Journal of Forestry Research 31(1): 245-256.

[21] Manea, A., Leishman, M. R. (2014): Leaf area index drives soil water availability and extreme drought-related mortality under elevated $\mathrm{CO}_{2}$ in a temperate grassland model system. - PloS One 9: e91046.

[22] Martínez-Murillo, J. F., Hueso-González, P., Ruiz-Sinoga, J. D. (2017): Topsoil moisture mapping using geostatistical techniques under different Mediterranean climatic conditions. - Science of the Total Environment 595: 400-412.

[23] Meerveld, T. V., Mcdonnell, J. J. (2006): On the interrelations between topography, soil depth, soil moisture, transpiration rates and species distribution at the hillslope scale. Advances in Water Resources 29: 293-310.

[24] Montes, F., Rubio, A., Barbeito, I., Cañellasb, I. (2008): Characterization of the spatial structure of the canopy in Pinus silvestris L. stands in Central Spain from hemispherical photographs. - Forest Ecology \& Management 255: 580-590.

[25] Nijland, W., Van der Meijde, M., Addink, E. A., De Jong, S. M. (2010): Detection of soil moisture and vegetation water abstraction in a Mediterranean natural area using electrical resistivity tomography. - Catena $81: 209-216$.

[26] Özkan, U., Gökbulak, F. (2017): Effect of vegetation change from forest to herbaceous vegetation cover on soil moisture and temperature regimes and soil water chemistry. Catena 149: 158-166. 
[27] Paluch, J. G., Gruba, P. (2012): Inter-crown versus under-crown area: contribution of local configuration of trees to variation in topsoil morphology, $\mathrm{pH}$ and moisture in Abies alba Mill. forests. - European Journal of Forest Research 131: 857-870.

[28] Pielou, E. C. (1966): The measurement of diversity in different types of biological collections. - Journal of Theoretical Biology 13: 131-144.

[29] Pueyo, Y., Moretfernández, D., Arroyo, A. I., Frutos Tena, Á. D., Saiz, H., López Alados, C. (2014): Spatio-temporal dynamics of soil water in a semi-arid Mediterranean ecosystem: implications for plant dynamics and spatial pattern. - EGU General Assembly Conference Abstracts 16: 1667P.

[30] Qi, F., Liu, Y. S., Mikami, M. (2004): Geostatistical analysis of soil moisture variability in grassland. - Journal of Arid Environments 58(3): 357-372.

[31] Ronda, R. J., Den Hurk, V., Holtslag, A. A. M. (2002): Spatial heterogeneity of the soil moisture content and its impact on the surface flux densities and near-surface meteorology. - Journal of Hydrometeorology 3(5): 556-570.

[32] Rossi, R. E., Mulla, D. J., Journel, A. G., Franz, E. H. (1992): Geostatistical Tools for Modeling and Interpreting Ecological Spatial Dependence. - Ecological Monographs 62: 277-314.

[33] Sánchez-González, A., López-Mata, L. (2005): Plant species richness and diversity along an altitudinal gradient in the Sierra Nevada, Mexico. - Diversity and Distributions 11: 567-575.

[34] Shannon, C., Wiener, W. (1949): The mathematical theory of communication. University of IIIinois Press, Urbana, USA.

[35] Shen, Y. Y., Ji, Y., Li, C. R., Luo, P. P., Wang, W. K., Zhang, Y., Nover, D. (2018): Effects of phytoremediation treatment on bacterial community structure and diversity in different petroleum-contaminated soils. - International Journal of Environmental Research and Public Health 15(10): 2168.

[36] Shi, W. Y., Du, S., Morina, J. C., Guan, J. H., Wang, K. B., Ma, M. G., Yamanaka, N., Tateno, R. (2017): Physical and biogeochemical controls on soil respiration along a topographical gradient in a semiarid forest. - Agricultural \& Forest Meteorology 247: $1-11$.

[37] Simpson, E. H. (1949): Measurement of diversity. - Nature 163: 688-688.

[38] Singh, R., Sagar, R., Srivastava, P., Singh, P., Singh, J. S. (2017): Herbaceous species diversity and soil attributes along a forest-savanna-grassland continuum in a dry tropical region. - Ecological Engineering 103: 226-235.

[39] Smith, M. D., Knapp, A. K. (2006): Physiological and Morphological Traits of Exotic, Invasive Exotic, and Native Plant Species in Tallgrass Prairie. - International Journal of Plant Sciences 162: 785-792.

[40] Sreelash, K., Sharma, R. K., Gayathri, J. A., Upendra, B., Padmalal, D. (2018): Impact of rainfall variability on river hydrology: a case study of southern western Ghats, India. Journal of the Geological Society of India 92: 548-554.

[41] Takagi, K., Harazono, Y., Noguchi, S. I., Miyata, A., Mano, M., Komine, M. (2006): Evaluation of the transpiration rate of lotus using the stem heat-balance method. Aquatic Botany 85(2): 129-136.

[42] Von Arx, G., Graf Pannatier, E., Thimonier, A., Rebetez, M. (2013): Microclimate in forests with varying leaf area index and soil moisture: potential implications for seedling establishment in a changing climate. - Journal of Ecology 101: 1201-1213.

[43] Wang, X. B., Zhou, B. Y., Sun, X. F., Yang, Y., Wei, M., Ming, Z. (2015): Soil tillage management affects maize grain yield by regulating spatial distribution coordination of roots, soil moisture and nitrogen status. - PloS One 10(6): e0129231.

[44] Wei, X., Bi, H. X., Liang, W. J., Hou, G. R., Kong, L. X., Zhou, Q. Z. (2018): Relationship between soil characteristics and stand structure of Robinia pseudoacacia L. and Pinus tabulaeformis Carr. mixed plantations in the Caijiachuan Watershed: An application of structural equation modeling. - Forests 9: 124. 
[45] Western, A. W., Blöschl, G., Grayson, R. B. (1998): Geostatistical characterisation of soil moisture patterns in the Tarrawarra catchment. - Journal of Hydrology 205: 20-37.

[46] Wubs, E. R. J., Bezemer, T. M. (2018): Plant community evenness responds to spatial plant-soil feedback heterogeneity primarily through the diversity of soil conditioning. Functional Ecology 32(2): 509-521.

[47] Yu, H. W., Shen, N., Yu, D., Liu, C. H. (2019): Effects of temporal heterogeneity of water supply and spatial heterogeneity of soil nutrients on the growth and intraspecific competition of bolboschoenus yagara depend on plant density. - Frontiers in Plant Science 9: 1987. 